\title{
Typing of Staphylococcus aureus obtained from mastitic milk of cattle and buffalo on the basis of two virulence-associated genes (spa and clfA)
}

\author{
Rahul Yadav ${ }^{1}$, Sandeep Kumar Sharma ${ }^{2}$, Jyotika Yadav ${ }^{3}$ and Anil Kumar Kataria ${ }^{1}$
}

\begin{abstract}
1. Department of Veterinary Microbiology and Biotechnology, College of Veterinary and Animal Sciences, Rajasthan University of Veterinary and Animal science, Bikaner, Rajasthan, India; 2. Department of Veterinary Microbiology and Biotechnology, Post Graduate Institute of Veterinary Education and Research, Rajasthan University of Veterinary and Animal Science, Jaipur, Rajasthan, India; 3. College of Veterinary and Animal Sciences, Hisar, Lala Lajpat Rai University of Veterinary \& Animal Sciences, Hisar, Haryana, India.

Corresponding author: Rahul Yadav, e-mail: drrahul16889@gmail.com, SKS: drsharmask01@hotmail.com, JY: drjyotika2910@gmail.com, AKK: akkataria1@rediffmail.com.

Received: 01-01-2015, Revised: 10-02-2015, Accepted: 16-02-2015, Published online: 26-03-2015
\end{abstract}

doi: 10.14202/vetworld.2015.398-402. How to cite this article: Rahul Yadav, Sandeep Kumar Sharma, Jyotika Yadav and Anil Kumar Kataria (2015) Typing of Staphylococcus aureus obtained from mastitic milk of cattle and buffalo on the basis of two virulence-associated genes (spa and clfA), Veterinary World 8(3):398-402.

\begin{abstract}
Aim: The present study was undertaken to type Staphylococcus aureus isolates from cattle and buffalo mastitic milk on the basis of spa (X-region) and clfA genes, both responsible for producing virulence factors.

Material and Methods: In the present investigation $S$. aureus isolates were isolated as per standard protocols. Typing of $S$. aureus was carried out by molecular detection of spa and clfA gene by polymerase chain reaction.

Results: All the 32 isolates from cattle (16) and buffalo (16) were divisible into seven spa types with amplicon sizes ranging between 120 and 380bp. The cattle isolates produced seven different spa amplicons of 120, 150, 200, 250, 280, 300, and 330 bp with 3, 4, 6, 8, 10, 11 and 12 number of tandem repeats, respectively whereas buffalo isolates were divisible into five spa types with amplicons of 150, 200, 250, 330 and 380 bp having calculated number of repeats of 5, 7, 9, 12, and 14 , respectively. Of the total isolates, 24 were considered pathogenic on the basis of more than seven number of tandem repeats. In the present investigation, clfA gene was amplified in 27 isolates from cattle and buffalo producing two different amplicons of 900 and 1000 bp sizes showing polymorphism. The most $(71.80 \%)$ of the isolates produced amplicons of $900 \mathrm{bp}$ while amplicon size of $1000 \mathrm{bp}$ was produced by four $(12.5 \%)$ of the isolates.
\end{abstract}

Conclusion: The presence of these genes with a wide degree of polymorphism confirmed the pathogenic potential of $S$. aureus and their association with clinical manifestations in mastitis among cattle and buffalo.

Keywords: buffalo, cattle, clfA gene, mastitis, Staphylococcus aureus, spa (X-region) gene.

\section{Introduction}

Protein A of Staphylococcus aureus, one of the important virulence factors encoded by spa gene is a surface protein that binds to the $\operatorname{IgG}$ molecules and evades phagocytosis thus in turn contributing to the development of the disease [1,2]. The spa gene is composed of functionally distinct regions, i.e. Fc binding region, $\mathrm{X}$-region and at $\mathrm{C}$-terminus. The $\mathrm{X}$-region of the spa gene includes a variable number of 24-bp repeats [3,4] and because of this the spa genes have been the most widely used markers for molecular typing. Polymerase chain reaction-restricted fragment length polymorphism (PCR-RFLP) studies of these genes were found to be quite useful in typing $S$. aureus strain and have been considered good in regards to typability, reproducibility and discriminatory power [5]. The strains with more than seven repeats in the $\mathrm{X}$-region have also been considered to be pathogenic[6].

Copyright: The authors. This article is an open access article licensed under the terms of the Creative Commons Attributin License (http:// creative commons.org/licenses/by/2.0) which permits unrestricted use, distribution and reproduction in any medium, provided the work is properly cited.
Clumping factor is an important adhesion protein of $S$. aureus that is governed by clfA gene [6] and is thought to be essential for colonization and establishment of infections. It participates in the infection process by facilitating bacterial binding via soluble or immobilized fibrinogen as fibrinogen plays a significant role in platelet thrombus formation [7]. Clumping factor has been reported to be present in the majority of isolates [8] and the gene clfA has been reported to be important in pathogenicity of bovine mastitis [6]. Tuchscherr et al. [9] showed that antibodies to clfA enhanced the protection against infection provided by capsular polysaccharides antibodies.

The present work reports spa (X-region) and clfA gene typing in $S$. aureus obtained from milk from cattle and buffalo with clinical mastitis.

\section{Materials and Methods}

\section{Ethical approval}

All the procedures have been carried out in accordance with the guidelines laid down by the Institutional Ethics Committee and in accordance with local laws and regulations. 


\section{Isolation of $\boldsymbol{S}$. aureus}

In the present investigation, $32 \mathrm{~S}$. aureus (16 each from cattle and buffalo) were isolated from mastitic milk and identified as per standard procedures [10]. All phenotypically identified isolates were further confirmed by $23 \mathrm{~S}$ rRNA ribotyping [11].

\section{Amplification of spa and clfA gene}

Amplification of the spa gene was done as described by Frenay et al. [12] using 5'CAAGCACCAAAAGAGGAA3' (F) and 5'CACCAGGTTTAACGACAT3' (R) primers. Briefly, the reaction mixture of $30 \mu$ was prepared by mixing $20.4 \mu \mathrm{l}$ deionised water, $2.5 \mu 110 \mathrm{x}$ Buffer, $1.8 \mu \mathrm{l} \mathrm{MgCl}, 1.0 \mu \mathrm{l}$ Primer-1 $(10 \mathrm{pM} / \mu \mathrm{l}), 1.0 \mu \mathrm{l}$ Primer-2 $(10 \mathrm{pM} / \mu \mathrm{l}), 0.6 \mu \mathrm{dNTP}-\operatorname{mix}(10 \mathrm{mM})$, $0.2 \mu \mathrm{Taq}$ DNA polymerase $(5 \mathrm{U} / \mu \mathrm{l})$ and $2.5 \mu \mathrm{ltem}$ plate DNA $(25 \mathrm{ng} / \mu \mathrm{l})$. Amplification was carried out in a Veriti thermal cycler (Applied biosystem) as follows: initial 34 cycle of amplification (denaturation at $94^{\circ} \mathrm{C}$ for $60 \mathrm{~s}$, primer annealing at $55^{\circ} \mathrm{C}$ for $60 \mathrm{~s}$ and primer extension at $70^{\circ} \mathrm{C}$ for $60 \mathrm{~s}$ ), and final extension at $72^{\circ} \mathrm{C}$ for $5 \mathrm{~min}$.

Amplification of the clfA gene was done as described by Stephan et al. [6] using 5'GGCTTCAGTGCTTGTAGG3' (F) and 5'TTTTCAGGGTCAATATAAG 3' (R) primers. Briefly, the reaction mixture of $30 \mu$ was prepared by mixing $21.4 \mu \mathrm{l}$ deionised water, $3.0 \mu \mathrm{l} 10 \mathrm{x}$ Buffer, $1.8 \mu \mathrm{l} \mathrm{MgCl}_{2} 1.0 \mu \mathrm{l}$ Primer-1 (10 pM/ $\left.\mu \mathrm{l}\right), 1.0 \mu \mathrm{l}$ Primer-2 $(10 \mathrm{pM} / \mu \mathrm{l}), 0.6 \mu \mathrm{lNTP}-\operatorname{mix}(10 \mathrm{mM}), 0.2 \mu \mathrm{l}$ Taq DNA polymerase $(5 \mathrm{U} / \mu \mathrm{l})$ and $1.0 \mu \mathrm{l}$ template DNA $(25 \mathrm{ng} / \mu \mathrm{l})$. Amplification was carried out in a Veriti thermal cycler (Applied biosystem) as follows: Initial 34 cycle of amplification (denaturation at $94^{\circ} \mathrm{C}$ for $60 \mathrm{~s}$, primer annealing at $55^{\circ} \mathrm{C}$ for $60 \mathrm{~s}$ and primer extension at $70^{\circ} \mathrm{C}$ for $60 \mathrm{~s}$ ), and final extension at $72^{\circ} \mathrm{C}$ for $5 \mathrm{~min}$. The PCR products, after addition of $2 \mu \mathrm{l}$ of tracking dye were resolved in $1.2 \%$ agarose gels prepared in $\times 1.0$ TBE buffer containing $0.5 \mu \mathrm{g} / \mathrm{ml}$ of ethidium bromide. $50 \mathrm{bp}$ and $100 \mathrm{bp}$ DNA ladder were used as molecular marker. The amplification products were electrophoresed for 50-60 min at 100 Volts. The gel was then visualized under gel documentation system (ENDURO GDS).

\section{Results}

The ribotyping produced an amplicon of $1250 \mathrm{bp}$ in 32 isolates confirming them to be $S$. aureus.

\section{Amplification of spa-X region gene}

Protein A, encoded by the spa gene, is one of the virulence factors involved in the staphylococcal pathogenesis. The amplification of $\mathrm{X}$ region of the spa gene produces amplicons of variable sizes depending on the number of $24 \mathrm{bp}$ tandem repeats and this property of the organisms is being used for differentiation among various isolates by the scientists $[6,13-15]$. The number of repeats in the $\mathrm{X}$ region of the spa gene correlates with the virulence level of the strains. In the present investigation all the isolates from both cattle and buffalo produced spa amplicons of seven types ranging between 120 and $380 \mathrm{bp}$ (Figures-1 and 2). The spa gene X-region amplicons produced by cattle isolates were of greater variability than that of isolates from buffalo. The cattle isolates produced seven different types of spa amplicons viz. $120,150,200,250,280,300$, and 330 bp with calculated number of repeats of $3,4,6,8,10,11$ and 12 , respectively (Table- 1). The buffalo isolates produced 5 types of spa amplicons the sizes of which were 150 , $200,250,330$ and 380 with calculated number of repeats of $5,7,9,12$, and 14 , respectively. The amplicon of $250 \mathrm{bp}$ was produced by maximum numbers of isolates (Table-2).

\section{Amplification of clfA gene}

Clumping factor $\mathrm{A}(\mathrm{cl} f \mathrm{~A})$ is a cell surface-associated protein of $S$. aureus that promotes binding of this pathogen to both soluble and immobilized fibrinogen and thought to be essential for colonization. Gene clfA has been reported to be important in pathogenicity of bovine mastitis [6]. In the present investigation, clf A gene was amplified in 27 out of 32 isolates from cattle and buffalo producing two different amplicons of 900 and $1000 \mathrm{bp}$ sizes showing polymorphism (Figures-3 and 4). The most $(71.80 \%)$ of the isolates produced amplicons of $900 \mathrm{bp}$ while amplicon size of $1000 \mathrm{bp}$ was produced by four (12.5\%) of the isolates.

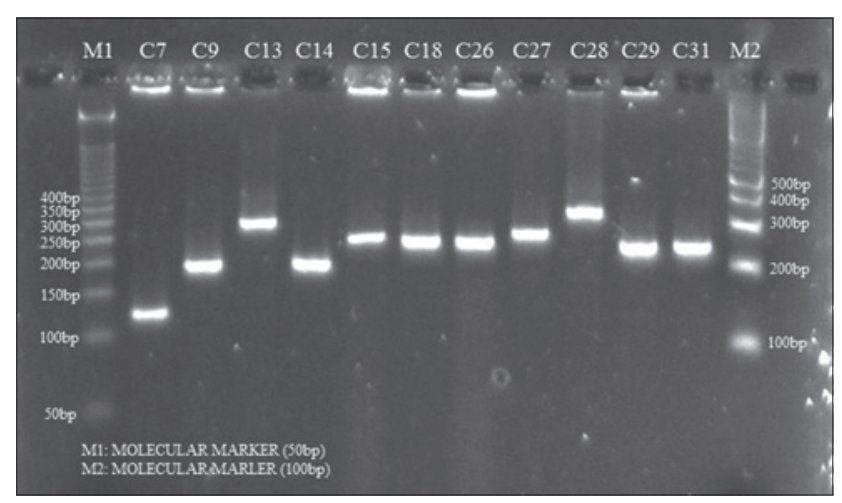

Figure-1: Agarose gel electrophoresis of amplicons of spa gene (X-region) of $S$. aureus isolates obtained from cattle mastitic milk

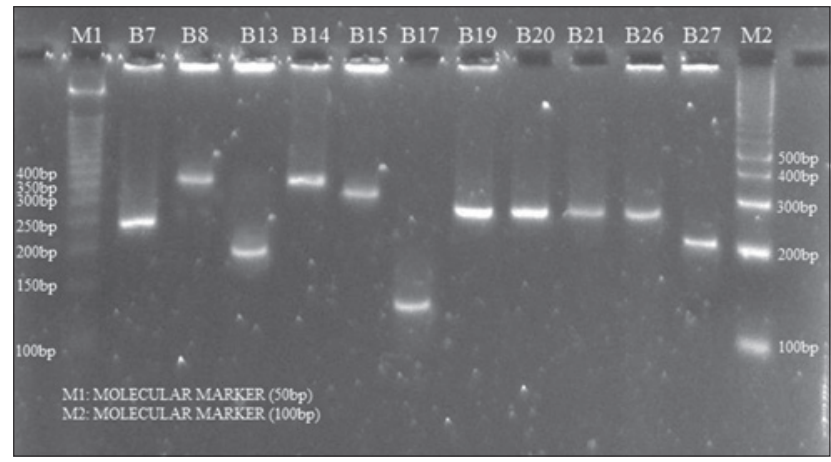

Figure-2: Agarose gel electrophoresis of amplicons of spa gene (X-region) of $S$. aureus isolates obtained from buffalo mastitic milk 
Table-1: spa gene (X-region) polymorphism in $S$. aureus isolates from cattle with clinical mastitis.

\begin{tabular}{lccc}
\hline $\begin{array}{l}\text { Isolate } \\
\text { numbers }\end{array}$ & $\begin{array}{c}\text { Total } \\
\text { isolates }\end{array}$ & $\begin{array}{c}\text { Spa gene } \\
\text { amplicon (bp) }\end{array}$ & $\begin{array}{c}\text { Total number } \\
\text { of repeats }\end{array}$ \\
\hline C37 & 1 & 120 & 3 \\
C7 & 1 & 150 & 4 \\
C9, C14, C23 & 3 & 200 & 6 \\
C15, C18, C26, & 6 & 250 & 8 \\
C29, C31, C38 & & & \\
C27, C36 & 2 & 280 & 10 \\
C13 & 1 & 300 & 11 \\
C24, C28 & 2 & 330 & 12 \\
\hline
\end{tabular}

S. aureus $=$ Staphylococcus aureus

Table-2: spa gene (X- region) polymorphism in S. aureus isolates from buffalo with clinical mastitis.

\begin{tabular}{lccc}
\hline $\begin{array}{l}\text { Isolate } \\
\text { numbers }\end{array}$ & $\begin{array}{c}\text { Total } \\
\text { isolates }\end{array}$ & $\begin{array}{c}\text { Spa gene } \\
\text { amplicon (bp) }\end{array}$ & $\begin{array}{c}\text { Total number } \\
\text { of repeats }\end{array}$ \\
\hline B17 & 1 & 150 & 4 \\
B13, B27 & 1 & 200 & 6 \\
B3, B7, B19, & 9 & 250 & 8 \\
B20, B21 B26, & & & \\
B37, B38, B43 & 2 & 330 & 12 \\
B15, B30 & 2 & 380 & 14 \\
B8, B14 & 2 & \\
\hline
\end{tabular}

S. aureus=Staphylococcus aureus

The remaining five $(15.6 \%)$ isolates were considered clfA deficient.

\section{Discussion}

\section{Amplification of Spa (X-region) gene}

Our observations were in complete agreement with many workers such as Salasia et al. [8] who obtained nine different sized amplicons of 100, 150, 200, 230, 240, 250, 270, 290 and 340 bp in S. aureus isolates from bovine subclinical mastitis, Annemuller et al. [16] who obtained amplified fragments of $120,150,170,250$ and 300 bp with calculated number of repeats of $3,4,5,8$ and 10 respectively and Indrajulianto [17] who studied X-region of protein-A yielding amplicons of variable size viz. 100, 150, 200, 250, 280, 300 and $330 \mathrm{bp}$.

Marques et al. [18] reported presence of spa gene in all of the isolates from bovine mastitis, showing variable amplicon sizes with $300 \mathrm{bp}$ being the prevalent size. Contrary to the results in the present study, uniform amplicons of $300 \mathrm{bp}$ size were obtained by Suleiman et al. [19] in 20 isolates of $S$. aureus from subclinical bovine mastitis. The $S$. aureus isolates have also been reported to be spa gene-deficient by Shakeri et al. [20].

In the present study, 24 isolates were considered pathogenic since they possessed more than seven repeats. On the other hand, no correlation was reported between tandem repeats and pathogenicity of the isolates by Nashev et al. [21] from humans, Kuzma et al. [4] and Jakubczak et al. [22] in isolates from mastitc cows and Kurlenda et al. [23] in human isolates.

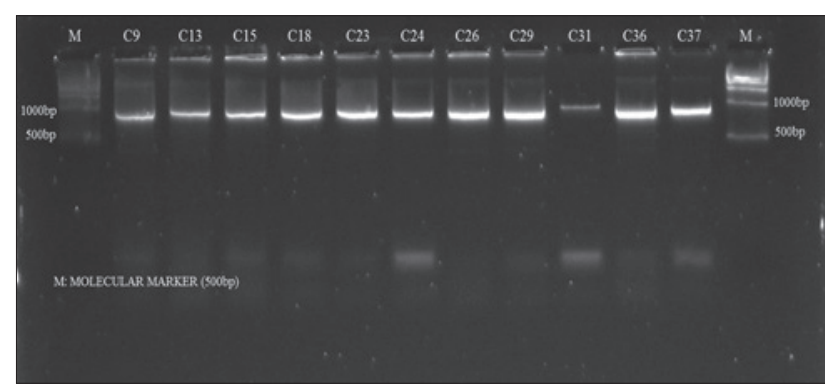

Figure-3: Agarose gel electrophoresis of amplicons of clfA gene of $S$. aureus isolates obtained from cattle mastitic milk

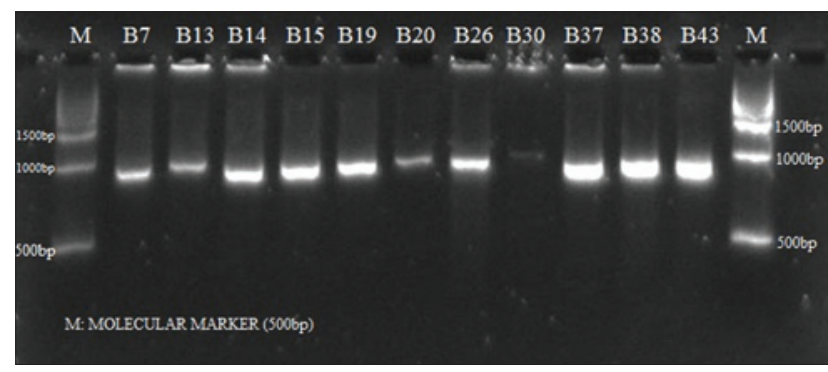

Figure-4: Agarose gel electrophoresis of amplicons of clfA gene of $S$. aureus isolates obtained from buffalo mastitic milk

\section{Amplification of clfA gene}

Our results were in complete agreement with Karahan et al. [7] who reported $84(91.3 \%)$ out of $92 \mathrm{~S}$. aureus isolates to show presence of clfA with two different amplicons at the molecular length of approximately $900 \mathrm{bp}$ and $1000 \mathrm{bp}$. Similarly, Memon et al. [24] also reported that the size of clfA gene amplicon varied from $900 \mathrm{bp}$ to $1000 \mathrm{bp}$ in $S$. aureus isolates associated with bovine mastitis. Among the $S$. aureus strains representing the clinical mastitic cow, 13 strains (54.2\%) had an amplicon size of $900 \mathrm{bp}$, while 11 strains $(45.8 \%)$ had an amplicon size of $1000 \mathrm{bp}$ and the $S$. aureus strains obtained from sub-clinical mastitis $2(12.5 \%)$ strains had a clfA amplicon size of $900 \mathrm{bp}$ and $14(87.5 \%)$ strains an amplicon size of $1000 \mathrm{bp}$ [25].

On the contrary to our observations, polymorphism was not reported for this gene by many workers. Stephan et al. [6] recorded amplicon with a size of approximately $980 \mathrm{bp}$ for all 34 S. aureus. Likewise, other workers [26-28] also found amplicons of same sizes with no polymorphism. Akineden et al. [2] and Salasia et al. [8] reported amplification of the clumping factor gene $c l f \mathrm{~A}$ resulting in a single amplicon with a size of approximately $1000 \mathrm{bp}$ from $S$. aureus. Similarly, Kalorey et al. [29] characterized 37 strains of $S$. aureus of bovine milk origin for $c l f \mathrm{~A}$ gene and obtained an amplicon of approximately 1042 bp only. Likewise, Moroni et al. [30] characterized S. aureus isolated from milk from chronically infected alpine dairy goats and obtained a clfA amplicon of $1030 \mathrm{bp}$ in all 28 isolates. Nathawat [31] also reported amplicons of $1050 \mathrm{bp}$ in isolates from the goat mastitis from same study area. In study of Salem-Bekhit et al. [27] also, amplification of the clumping factor (clfA) gene 
resulted in a single amplicon with a size of approximately 985 bp for all $68 \mathrm{~S}$. aureus strains indicating no size polymorphisms of this gene.

\section{Conclusion}

The present study revealed presence of $s p a$ and clfA gene with a wide degree of polymorphism. It directly correlates with the pathogenic potential of an organism and their association with clinical manifestations in mastitis among cattle and buffalo. In the present study, 24 isolates were considered pathogenic since they possessed more than seven repeats. The number of repeats along the $\mathrm{X}$ region of the spa gene correlates with the virulence level of the strains. Likewise, clfA gene polymorphism was also recorded among isolates.

\section{Authors' Contributions}

RY and AKK planned and designed the study. RY and SKK conduct the experiment. Lab analysis was carried out by RY and JY. Writing of the manuscript is done by RY and JY under the guidance of AKK. All authors read and approved the final manuscript.

\section{Acknowledgment}

The study was funded by Rajasthan University of Veterinary and Animal Sciences University (RAJUVAS), Bikaner as part of MVSc dissertation of the first author. The authors are highly thankful to the Department of Veterinary Microbiology and Biotechnology, College of Veterinary and Animal Sciences, RAJUVAS for providing necessary facilities.

\section{Competing Interests} interests.

The authors declare that they have no competing

\section{References}

1. Sharma, N.K., Rees, C.E.D. and Dodd, C.E.R. (2000) Development of a single-reaction multiplex PCR toxin typing assay for Staphylococcus aureus strain. Appl. Environ. Microbiol., 66(4): 1347.

2. Akineden, O., Annemuller, C., Hassan, A.A., Lammler, C., Wolter, W. and Zschock, M. (2001) Toxin genes and other characteristics of Staphylococcus aureus isolates from milk of cows with mastitis. Clin. Diagn. Lab. Immunol., 8(5): 959-964.

3. Frenay, H.M., Theelen, J.P., Schouls, L.M., VandenbrouckeGrauls, C.M., Verhoef, J., van Leeuwen, W.J. and Mooi, F.R. (1994) Discrimination of epidemic and nonepidemic methicillin- resistant Staphylococcus aureus strains on the basis of Protein-A gene polymorphism. J. Clin. Microbiol., 32(3): 846-847.

4. Kuzma, K., Malinowski, E., Lassa, H. and Klossowska, A. (2003) Specific detection of Staphylococcus aureus by PCR in intramammary infection. Bull. Vet. Inst. Pulawy., 47: 183-190.

5. Mehndiratta, P.L., Bhalla, P., Ahmed, A. and Sharma, Y.D. (2009) Molecular typing of methiciline-resistance Staphylococcus aureus by PCR-RFLP of spa gene: A reference laboratory prospective. Indian. J. Vet. Microbiol., 27(2): 116-122.

6. Stephan, R., Annemuller, C., Hassan, A. and Lammler, C. (2001) Characterization of enterotoxigenic Staphylococcus aureus strains isolated from bovine mastitis in north-east Switzerland. Vet. Microbiol., 78: 373-382.

7. Karahan, M., Nuri Aciki, M. and Cetinkaya, B. (2011) Investigation of virulence genes by PCR in Stapylococcus aureus isolates originated from subclinical bovine mastitis in Turkey. Pak. Vet. J., 31(3): 249-253.

8. Salasia, S.I.O., Khusnan, Z., Lammler, C. and Zschock, M. (2004) Comparative studies on phenotypic and genotypic properties of Staphylococcus aureus isolated from bovine subclinical mastitis in central Java in Indonesia and Hesse in Germany. J. Vet. Sci., 5(2), 103-109.

9. Tuchscherr, L.P.N., Buzzola, F.R., Alvarez, L.P., Lee, J.C. and Sordelli, D.O. (2008) Antibodies to capsular polysaccharide and Clumping factor A prevent mastitis and the emergence of unencapsulated and small-colony variants of Staphylococcus aureus in mice. Infect. Immunol. 76(12): 5738-5744.

10. Quinn, P.J., Carter, M.E., Markey, B.K and Carter, G.R. (1994) Clinical Veterinary Microbiology. Wolfe Publishing, Mosby-Year Book Europe Ltd., England.

11. Straub, J.A., Hertel, C. and Hammes, W.P. (1999). A $23 \mathrm{~S}$ rRNA target polymerase chain reaction based system for detection of Staphylococcus aureus in meat starter cultures and dairy products. J. Food. Protect., 62(10): 1150-1156.

12. Frenay, H.M.E., Bunschoten, A.E., Schouls, L.M., Van Leeuwen, W.J., Vandenbroucke-Grauls, C.M., Verhoef, J and Mooi, F.R. (1996) Molecular typing of methicillin-resistant Staphylococcus aureus on the basis of protein A gene polymorphism. Eur. J. Clin. Microbiol. Infect. Dis., 15(1): 60-64.

13. Lange, C., Cardoso, M., Senczek, D. and Schwarz, S. (1999) Molecular subtyping of Staphylococcus aureus isolates from cases of bovine mastitis in Brazil. Vet. Microbiol., 67: 127-141.

14. Singh, R.S., Kumar, R. and Yadav, B.R. (2011) Distribution of pathogenic factors in Staphylococcus aureus strains isolated from intra-mammary infections in cattle and buffaloes. Indian J. Biotechnol., 10: 410-416.

15. Khichar, V., Kataria, A.K. and Sharma, R. (2012) Characterization of Staphylococcus aureus of cattle mastitis origin for two virulence - Associated genes (coa and spa). Comp. Clin. Pathol., 23(3): 603-611.

16. Annemuller, C., Lammlera, C. and Zschock, M. (1999). Genotyping of Staphylococcus aureus isolated from bovine mastitis. Vet. Microbiol., 69: 217-224

17. Indrajulianto, S. (2000) Protein-A gene polymorphism of Staphylococcus aureus isolated from bovine and humans. Indones. J. Biotechnol., (12), 419-424.

18. Marques, V.F., de Souza, M.M.S., de Mendonca, E.C.L., de Alencar, T.A., Pribul, B.R., Coelho, S.M.O. and Reinoso, M.L.E. (2013) Phenotypic and genotypic analysis of virulence in Staphylococcus spp. and its clonal dispersion as a contribution to the study of bovine mastitis. Pesqui. Vet. Brasil., 33(2):161-170.

19. Suleiman, A.B., Kwaga, J.K.P., Umoh, V.J., Okolocha, E.C., Muhammed, M., Lammler, C., Shaibu, S.J., Akineden, O. and Weiss, R. (2012) Macro-restriction analysis of Staphylococcus aureus isolated from subclinical bovine mastitis in Nigeria. Afr. J. Microbiol. Res. 6(33): 6270-6274.

20. Shakeri, F., Shojai, A., Golalipour, M., Alang, S.R., Vaez, H. and Ghaemi, E.A. (2010). Spa diversity among MRSA and MSSA strains of Staphylococcus aureus in north of Iran. Int. J. Microbiol., 2010: 351397.

21. Nashev, D., Toshkova, K., Salasia, S.I., Hassan, A.A., Lammler, C. and Zschock, M. (2004) Distribution of virulence genes of Staphylococcus aureus isolated from stable nasal carriers. FEMS. Microbiol. Lett., 233(1): 45-52.

22. Jakubczak, A., Szweda, P., Lukaszewska, K. and Kur, J. (2007) Molecular typing of Staphylococcus aureus isolated from cows with mastitis in the east of Poland on the basis of polymorphism of genes coding protein A and coagulase. 
Pol. J. Vet. Sci., 10(4): 199-205.

23. Kurlenda, J., Grinholc, M. and Szweda P. (2010). Lack of correlation between $\mathrm{X}$ region spa polymorphism and virulence of methicillin resistant and methicillin sensitive Staphylococcus aureus strains. Acta Biochim. Pol., 57(1): 135-138.

24. Memon, J., Yang, Y., Kashif, J., Yaqoob, M., Buriro, R., Soomro, J., Liping, W. and Hongjie, F. (2013) Genotypes, virulence factors and antimicrobial resistance genes of Staphylococcus aureus isolated in bovine subclinical mastitis from Eastern China. Pak. Vet. J., 33(4): 486-491.

25. El-Sayed, A., Alber, J., Lammler, C., Jager, S., Wolter, W. and Castaneda-Vazquez, H. (2005) Comparative study on genotypic properties of Staphylococcus aureus isolated from clinical and subclinical mastitis in Mexico. Vet. Mexico., 37(6): 165-179.

26. Bhanderi, B.B., Roy, A., Yadav M.M. and Joshi, C.G. (2009) PCR based detection of virulence associated genes of Staphylococcus aureus from clinical and subclinical bovine mastitis. R. Vet. J. Ind., I\&II(5): 20-26.

27. Salem-Bekhit, M.M., Muharram, M.M., Alhosiny, I.M. and
Hashim, M.E.S.Y. (2010) Molecular detection of genes encoding virulence determinants in Staphylococcus aureus strains isolated from bovine mastitis. J. Appl. Sci. Res., 6(2): 121-128

28. Momtaz, H., Tajbakhsh, E., Rahimi, E. and Momeni, (2011) Coagulase gene polymorphism of Staphylococcus aureus isolated from clinical and sub-clinical bovine mastitis. Comp. Clin. Pathol., 20: 519-522.

29. Kalorey, D.R., Shanmugam, Y., Kurkure, N.V., Chousalkar, K.K. and Barbuddhe, S.B. (2007). PCR-based detection of genes encoding virulence determinants in Staphylococcus aureus from bovine subclinical mastitis cases. J. Vet. Sci., 8 (2), 151-154.

30. Moroni, P., Pisoni, G., Vimercati, C., Rinaldi, M., Castiglioni, B., Cremonesi, P. and Boettcher, P. (2005) Characterization of Staphylococcus aureus isolated from chronically infected dairy goats. J. Dairy Sci., 88: 3500-3509.

31. Nathawat, P., Bhati, T., Sharma, S.K., Mohammed, N. and Kataria, A.K. (2013) Prevalence of Staphylococcus aureus in lactating goats with clinical mastitis and their antibiogram studies. Abah Int. J. Bioflux, 5(1): 32-37. 